\title{
Combining Ability and Heterosis in Corn Breeding Lines to Forage and Grain
}

\author{
Cesar Guerrero Guerrero', Miguel A. Gallegos Robles²*, José Guadalupe Luna Ortega3, \\ Ignacio Orona Castillo4, Cirilo Vázquez Vázquez ${ }^{4}$, Mario García Carrillo ${ }^{4}$, \\ Alejandro Moreno Resendez ${ }^{4}$, Anselmo González Torres ${ }^{4}$ \\ ${ }^{1}$ Direccion General de Educación Tecnológica Industrial, Torreón, México \\ ${ }^{2}$ Universidad Juárez del Estado de Durango, Venecia Dgo, México \\ ${ }^{3}$ Catederatico de la Universidad Politécnica de la Región, Laguna, México \\ ${ }^{4}$ Catederaticos de la UAAAAUL,Torreon, México \\ Email: ${ }^{*}$ cesar gg47@hotmail.com
}

Received 16 December 2013; revised 16 February 2014; accepted 7 March 2014

Copyright @ 2014 by authors and Scientific Research Publishing Inc.

This work is licensed under the Creative Commons Attribution International License (CC BY). http://creativecommons.org/licenses/by/4.0/

(c) $\underset{\text { EY }}{0}$ Open Access

\section{Abstract}

This study was conducted in two stages, in 2006 the formation of cross, in the experimental field of the Universidad Autonoma Agraria Antonio Narro Unidad Laguna (UAAANUL), and the evaluation of the same in 2007; at two locations with three environments, a locality was the experimental field of UAAANUL during spring and summer cycles and another location was the Niagara, Municipality of Aguascalientes, during the spring cycle. The genetic material used consisted of three groups of lines: the first group formed by four lines from the UAAANUL, the second group, two lines from INIFAP, and the third group, 10 lines of the International Center for Maize Improvement and Wheat (CIMMYT). The main objective was to estimate the effects of general combining ability (GCA) of the lines, and the specific combining ability (SCA) of their crosses and heterosis, to estimate its use in a breeding program. Estimates of general combining ability (GCA) and specific combining ability (SCA) were obtained using an analysis of line $x$ line. To forage yield (FY), B-40 (16.84 th ha-1) and AN-447 (1.54 th ha $\left.{ }^{-1}\right)$ and to grain yield (GY), AN-388R $\left(2.31 \mathrm{t} \cdot \mathrm{ha}^{-1}\right)$ had the greatest effect of GCA in both types of yield. The greatest effects of SCA for (FY) were cross AN447XCML-264 (17.56 t.ha-1) and AN-388RXCML-319 (16.54 t.ha-1), in (GY) were cross AN447XCML-315 (1.94 t.ha-1) and B-40XCML-319 (1.78 t.ha-1). For heterosis, higher value in forage yield was cross AN-447XCML-264 (20.7\%), in grain yield, were B-40XCML-319 (27.1\%) and B$32 X C M L-319(22.1 \%)$ crosses. These results show that it is possible to structure a hybrid program using best lines from CIMMYT, INIFAP and UAAANUL.

\footnotetext{
*Corresponding author.
}

How to cite this paper: Guerrero, C.G., Robles, M.A.G., Ortega, J.G.L., Castillo, I.O., Vázquez, C.V., Carrillo, M.G., Resendez, A.M. and Torres, A.G. (2014) Combining Ability and Heterosis in Corn Breeding Lines to Forage and Grain. American Journal of Plant Sciences, 5, 845-856. http://dx.doi.org/10.4236/ajps.2014.56098 


\section{Keywords}

\section{Zea mays L.; Hybrids; Genetic Material; Crosses; SCA}

\section{Introduction}

Genetic improvement of maize, is a continuous process for forming hybrids and varieties. To enhance a crop, it is important to know the genetic component of the materials used as parents. In any breeding program, the selection of parent germplasm is one of the most important decisions to be taken. In this regard, [1] [2] mention that knowing combining ability of parents improves the efficiency of a breeding program. This allows parents to select good average behavior in a series of crosses, and identify specific combinations with higher than expected behavior. Heterosis is a phenomenon in which the F1 resulting from the crossing of two genotypes, is superior in growth, size, yield and vigor [1]. In this regard, [3] found maximum values of heterosis in tropical maize populations for high quality forage.

Among the methods for studying, the attributes of a set of parents are genetically engineering North Carolina I, proposed by [4], which identifies superior combinations. The term combining ability means the ability of an individual or a population has, combined with others, as measured by progeny [5]. However, in a population combining ability must be determined by several individuals in order to select those that exhibit the highest combining ability. The general combining ability (GCA), explains the proportion of genotypic variance due to the additive effects of genes, while specific combining ability (SCA) said the proportion of genotypic variance may be due to dominance deviations [6]. Crosses between warm tropical and subtropical germplasm obtained from $18.5 \%$ and $38.3 \%$ heterosis [6]-[8] mention that the maize breeding the desirable level for utilization of heterosis in crosses is at least $20 \%$.

Inbred lines of different origin, allowing you to explore the great genetic diversity presented in maize, properly handling this material can increase the heterotic response between them [9]. Combining ability information of the sources parental germplasm derived from them, is an important requirement in addition to considering the heterotic response to implement the hybridization efficiency, given the importance of combining inbred parents and not inbred or a combination of both [10]. However, during the selection process, it is important to consider not only the linear effects of genotype $\mathrm{x}$ environment, but also the interaction genotype $\mathrm{x}$ environment, because through it the efficiency of selection based on genotypic adaptation is detected across environments, which avoids the need to develop specific improvement programs for each particular environment [11] [12].

[13] indicated that it is possible to obtain up to $80 \mathrm{t}^{\mathrm{h}} \mathrm{ha}^{-1}$ of fresh forage and $24 \mathrm{t} \cdot \mathrm{ha} \mathrm{a}^{-1}$ dry (30\% dry matter) with a forage grain containing $45 \%$ to $50 \%$. Therefore the objective of this study was to estimate and quantify the gene action involved in the crosses of maize lines from elite and the general and specific combining ability, and heterosis of some agronomic traits to select experimental hybrids with high forage yield and grain.

\section{Materials and Methods}

The study was conducted in two parts: first the crosses were formed in the spring growing season of 2006, in the experimental field of Antonio Narro Agrarian Autonomous University Laguna (UAAANUL) Unit, geographically located between latitude $24^{\circ} 30^{\prime}$ and $27^{\circ}$ North Latitude, and $102^{\circ}$ and $104^{\circ} 40^{\prime}$ West Longitude, with 1150 msnm and a dry climate, warm, with average annual temperature of $20^{\circ} \mathrm{C}-22^{\circ} \mathrm{C}$, low rainfall, deficient rainfall in all seasons and average annual rainfall of $300 \mathrm{~mm}$, with rainfall in the months of September, October and November, the trade winds blow southward at speeds of 27 - $44 \mathrm{~km} \cdot \mathrm{hr}^{-1}$ [14].

The evaluation of the crosses was conducted in 2007 at two locations and three environments, the first location was the experimental field of UAAANUL, a cycle during the spring and other during the summer cycle, the second location was the Ejido Niagara, Municipality of Aguascalientes, during the spring cycle.

The Ejido Niagara, is located in the western region of the Mexican Plateau, at coordinates $21^{\circ} 53^{\prime}$ North Latitude, $102^{\circ} 18^{\prime}$ west longitude, with altitude of 1.870 meters above sea level, the climate is semi-arid, with mean annual temperature $17^{\circ} \mathrm{C}$, the highest temperatures occur in the months of April, May and June and the lowest in the months of November, December, January and February. Rainfall is $526 \mathrm{~mm}$ per year, with abundant rains in summer and low intensity the rest of the year. The trade winds blow towards South East-North West during the summer and part of fall [14]. 
The genetic material consisted of three groups of inbred lines: the first is used as male testers, consisted of four lines whose origin comes from the Universidad Autonoma Agraria Antonio Narro Unit Laguna (UAAANUL), which are characterized by their adaptation to climate the dry tropics, pest resistance and resistance to high temperatures. The second group, formed two male, from lines of the National Institute of Agricultural and Livestock Forestry Research (INIFAP), similar to the above features, and the third group, consisted of 11 lines from the International Center for the Improvement of Maize and Wheat (CIMMYT), which are characterized by their adaptation to tropical and humid subtropical climate, stress tolerance of biotic factors such as disease resistance and drought resistance [15]:

M1; L-AN 447. Line8selfing, derived from advanced generationsofhybridAN-447, with good adaptability.

M2; L-AN 130. Was derived from the fourth generation ofthecrossesofH-507x Celaya 2.

M3; L-AN 123. Formed from a Creole population of the Highlands Region, Municipality. Concepcion, Jalisco, possessing earliness and drought tolerance.

M4; L-AN 388R. Dwarf line, with broad vertical leaves, generated from the third generation of the hybrid AN-388.

M5; B-32. Línea de INIFAP derivada del híbrido H-353.

M6; B-40. Cuyo origen proviene de INIFAP-B40.

H1; CML-319 CIMMyT. RecyW89(Cr.Arg/CIM.ShPINPH)6-3-2-4-B-B.

H2; CML-264 Pob21 CIMMYT, POB21C5F219-3-1-B-_-8-1-3-BBB-f.

H3; CML-254 Pob21 CIMMYT, TUXSEQ-149-2-BBB-_-1-BB-F.

H4; CML-313 CIMMYT, Pob501c0F6-3-3-2-1-B-B.

H5; CML-273 Pob43 CIMMYT, (ACT643*43F7)-2-3-2-1-bb-F.

H6; CML-247 Pool24 CIMMYT, (G24F119*G24F54)-6-4-1-1-BB-f.

H7; CML-271 Pob29 CIMMYT, pob29stec1hc25-6-4-1-_-BBB-F.

H8; CML-278 Pob43 CIMMYT, DMANTES8043-53-1-1-b-_-1-BB-f.

H9; CML-315 CIMMYT, Pob500P500c0F246-4-1-2-2-B*3.

H10; CML-318 Recy W87[B810(66)S3/G24S2]-B-8-1-1-3-B*4.

H11; CML-321 Pop 502 P502c0F1-1-3-1-B*4.

Flowchart in crosses obtained from six male lines INIFAP and UAAANUL, with 11 females lines from CIMM-YT.

\begin{tabular}{|c|c|c|c|c|c|c|c|c|c|c|c|}
\hline & \multicolumn{11}{|c|}{ Female } \\
\hline Male & H1 & $\mathrm{H} 2$ & H3 & $\mathrm{H} 4$ & H5 & H6 & $\mathrm{H} 7$ & H8 & H9 & H10 & H11 \\
\hline M1 & M1XH1 & M1XH2 & M1XH3 & M1XH4 & M1XH5 & M1XH6 & M1XH7 & M1XH8 & M1XH9 & M1XH10 & M1XH11 \\
\hline M2 & M2XH1 & M2XH2 & M2XH3 & M2XH4 & M2XH5 & M2XH6 & M2XH7 & M2XH8 & М2Хн9 & M2XH10 & M2XH11 \\
\hline M3 & M3XH1 & М3ХH2 & М3ХНЗ & M3XH4 & M3XH5 & M3XH6 & M3XH7 & М3ХН8 & МЗХн9 & M3XH10 & M3XH11 \\
\hline M4 & M4XH1 & M4XH2 & M4XH3 & M4XH4 & M4XH5 & M4XH6 & M4XH7 & M4XH8 & М4XH9 & M4XH10 & M4XH11 \\
\hline M5 & M5XH1 & M5XH2 & M5XH3 & M5XH4 & M5XH5 & M5XH6 & M5XH7 & M5XH8 & М5XH9 & M5XH10 & M5XH11 \\
\hline M6 & M6XH1 & М6XH2 & M6XH3 & M6XH4 & M6XH5 & M6XH6 & M6XH7 & М6ХH8 & М6Хн9 & M6XH10 & M6XH11 \\
\hline
\end{tabular}

Sowing was done in the first locality, March 18, in the experimental field of UAAANUL during the spring cycle, and on June 21 during the summer cycle, the second location was, the Ejido Niagara of Aguascalientes municipality, which was seeded on 24 May during the spring cycle. Sowing was done manually, using two rows of $2 \mathrm{~m}$ length per parcel with row spacing of $0.75 \mathrm{~m}$, the experimental design of randomized complete block with two replications was used. Thirty days after emergence were thinned leaving six plants per linear meter and $16.6 \mathrm{~cm}$ between plants, for a population density of 80,000 plants per hectare.

Fertilization formula $200 \mathrm{~N}$ was applied, $90 \mathrm{P}, 00 \mathrm{~K}$, in two steps: $50 \%$ nitrogen and total phosphorus at the time of sailing, and the rest in the weeding at 42 days after sowing. Four irrigations were applied by gravity, one of sowing and three relief, ensuring that the plants do not suffer from stress during the crop.

Weed control was done manually, two weedings were given before spud and three after weeding earthing up the crop. Pests that arose were budworm (Spodoptera frugiperda) and the black flea (Chaetocnema pulicaria), 
the first was controlled with applying insecticide (Deltamethrin), with doses of $1.0 \mathrm{~L} \cdot \mathrm{ha}{ }^{-1}$ and in the case of the flea black, Lorsban (organophosphate insecticide) was used at $1.0 \mathrm{~L} \cdot \mathrm{ha}^{-1}$.

For the forage yield, the cuts were made at 116 days after planting, when the grain was in milk stage, at both locations with three main three plants per plot were taken, first proceeded to measure the plant height, then separated the three major components of green forage yield and weighed separately: the stem to the shank, the leaves of the plant with leaves and corn. Then he proceeded to take measurements of the diameter and length of the corn cob, then proceeded to get the average per plant in each of the features. For grain yield, harvest was made when the grain was $12 \%$ moisture three plants per plot were taken, the cobs were weighed, then proceeded to measure characteristics such as length, diameter, number of rows and kernels per row, then proceeded to flail cob to get the grain yield, the latter proceeded to take the averages for each of the characteristics evaluated. The variables evaluated were: forage yield (FY), stem weight (WS), weight of the leaves of the plant (WLP), weight of corn with leaves (WCL), plant height (PH), grain yield (GY), ear length (EL), ear diameter (ED), number of grains per row (NGR) and number of rows per ear (NRE). Statistical analysis for the evaluated variables was performed with the package [16], genetic analysis was performed with the design I mating NC, [4] with fixed effects, the linear model is:

Yijk $=\mu+\mathrm{Mi}+\mathrm{Hj}+\Phi \mathrm{ij} € \mathrm{ijk}$

Where $\mathrm{i}=1,2, \cdots \mathrm{m}$ (males); $\mathrm{j}=1,2, \cdots \mathrm{h}$ (females), $\mathrm{k}=1,2, \cdots \mathrm{r}$ (rep) Yijk = observation of cross between male-than djth female in the k-threpetition, $\mu$ = average general; $\mathrm{Mi}$ and $\mathrm{Hj}=$ effect of the ithandjth male female; $\Phi \mathrm{ij}$ = interaction effect of the ith male with $\mathrm{j}$-th female; €ijk = experimental error. The estimate of the effects of general combining ability (GCA) for males and females, and the specific combining ability (SCA) for the crosses, was made according to the proposal (SpragueandTatum1941), where: gi $=\bar{Y}_{i}-\bar{Y} \cdot \mathrm{g}_{\mathrm{j}}=\bar{Y}_{j}-\bar{Y}$.

$S_{i j}=Y_{i j}-g_{i}-g_{j}-\tilde{Y} \cdots$, and $g_{i}, g_{j}$ y $S_{i j}$ are the effects of GCA and SCA, respectively, for thei-males, j-females and theiri $\mathrm{j}$ cross; $\bar{Y}_{i}$ and $\bar{Y}_{j}$ are the means of males and females, $\mathrm{Y}_{\mathrm{ij}}$ is the value of crosses ixj and $\tilde{\mathrm{Y}}$. Is the overall mean of alli jcross.

\section{Results}

Analysis of variance showed significant differences $(\mathrm{p} \leq 0.01)$ in the variation source locations in all traits evaluated. This indicates that all variables showed a different behavior in each of the locations, and the importance of evaluation in a larger number of environments. The precipitation could be one of the factors that contributed to obtain the measured results, because in the state of Aguascalientes is a region where rains occur more frequently. In the sourse variation males $(M)$, all variables were highly significant ( $\mathrm{p} \leq 0.01)$, except EL, indicating that these features behave differently in the various lines used as males. For the source of variation cross $\mathrm{H}(\mathrm{M})$, only ear length, ear diameter and number of grains per row were significant $(\mathrm{p} \leq 0.01)$, plant height, number of rows per ear, resulted with significant $(p \leq 0.05)$ This may be due to the genetic diversity of the parents. In this regard, [17] found that as the genetic diversity of the parents increases, the differences between their crosses are increased in both agronomic and physiological characteristics. For the source of variation $\mathrm{L} * \mathrm{M}$, for forage yield, stem weight, leaf weight of the plant, plant height and grain yield. Indicating the differing effects of these variables, evaluated in male parents in different environments, the remaining variables showed the same behavior in males in different localities. For the crosses for locations $L * H(M)$, weight of corn with leaves, you shows the differences in the weight of the corn, in crosses evaluated in different environments, while the number of kernels per row, only had statistical significance at $(p \leq 0.05)$. The presence of acceptable variation coefficients of 7.24, 10.78, 12.17, 16.6 and 14.64 in the ED, NGR, PD, WLP and NRE, this variables indicated greater accuracy in their sampling not in WS, WCL, EL, FY variables and GY, with values of 18.2, 18.6, 19.51, 20.11 and $21.57 \%$, because these are the most complicated when measuring, so it is considered that these values are influenced by errors in sampling [18] (Table 1).

The average behavior of male parental lines. Shows that the M6 line was superior in FY, WS, WLP, WCL, PH and NGR with 106.2, 49.9, 18.2, $38.2 \mathrm{t}^{-\mathrm{ha}^{-1}}$ and $2.4 \mathrm{~m}$, plus NGR with 39.5. It was followed by the M1 with $90.9 \mathrm{t}^{-h^{-1}}{ }^{-1}$ in FY, 42.1, $15.2 \mathrm{t}^{-h^{-1}}{ }^{-1}$ and $2.3 \mathrm{~m}$ in WS, WLP and PH respectively. The M4 male was higher in GY, ED and NRE with $12.4 \mathrm{t} \cdot \mathrm{ha}^{-1}, 4.9 \mathrm{~cm}$ and 15.9 (Table 2), whereas that M2 on EL was higher with $19.5 \mathrm{~cm}$, although all were statistically equal. The average for the FY variable was of 89.36 and GY was $10.09 \mathrm{t}^{-h^{-1}}{ }^{-1}$, All variables contributed to performance to be major components for this character. The M6 and M1, male parents had the highest GCA values for FY and are those involved in higher yielding crosses. As these lines resulted 
Table 1. Mean squares of analysis of variance with the design I North Carolina and two in three main locations, UAAANUL Torreón, Coahuila, and Aguascalientes, Ags, 2007. (SV = Sources of variation, DF = Degrees of freedom, FY = fodder yield, WS = weight of stem, WLP = weight of the leaves of the plant, WCL = weight of corn with leaves, PH = plant height, $\mathrm{GY}=$ grain yield, $\mathrm{EL}=$ ear length, $\mathrm{ED}=$ ear diameter, $\mathrm{NGR}=$ number of grains per row, $\mathrm{NRE}=$ number of rows per ear. $\mathrm{CV}$ $=$ coefficient of variation. $\left.{ }^{*}=(\mathrm{p} \leq 0.05),{ }^{* *}=(\mathrm{p} \leq 0.01)\right)$.

\begin{tabular}{cccccccccccc}
\hline SV & DF & FY & WS & WLP & WCL & PH & GY & EL & ED & NGR & NRE \\
\hline L & 2 & $40230^{* *}$ & $17715^{* *}$ & $189^{* *}$ & $5237^{* *}$ & $17.6^{* *}$ & $77^{* *}$ & $190^{* *}$ & $1.9^{* *}$ & $204^{* *}$ & $34^{* *}$ \\
R (L) & 3 & $10049^{* *}$ & $1705^{* *}$ & $178^{* *}$ & $911^{* *}$ & $0.9^{* *}$ & $270^{* *}$ & 4 & $1.1^{* *}$ & $240^{* *}$ & 2 \\
M & 5 & $5625^{* *}$ & $2579^{* *}$ & $125^{* *}$ & $682^{* *}$ & $2.0^{* *}$ & $276^{* *}$ & 26 & $0.8^{* *}$ & $115^{* *}$ & $37^{* *}$ \\
H (M) & 60 & 654 & 196 & 19 & 122 & $0.1^{*}$ & 15 & $74^{* *}$ & $0.2^{* *}$ & $47^{* *}$ & $7^{*}$ \\
L * M & 10 & $1299^{* *}$ & $531^{* *}$ & $40^{* *}$ & 129 & $0.2^{* *}$ & $70^{* *}$ & 27 & 0.1 & 24 & 2 \\
L H (M) & 120 & 561 & 163 & 12 & $133^{* *}$ & 0.0 & 5 & 13 & 0.0 & $23^{*}$ & 2 \\
ERROR & 195 & 544 & 162 & 14 & 93 & 0.0 & 14 & 30 & 0.1 & 16 & 4 \\
MEDIA & & 89.36 & 39.2 & 15.44 & 33.7 & 2.15 & 10.09 & 18.78 & 4.70 & 38.21 & 14.57 \\
CV (\%) & & 20.11 & 18.4 & 14.6 & 18.6 & 12.17 & 21.57 & 19.51 & 7.24 & 10.78 & 14.64 \\
\hline
\end{tabular}

Table 2. Average yield in $t^{\cdot h} \mathrm{~h}^{-1}$ of the six maize inbred lines used as male, four from UAAANUL and two from INIFAP, according to the analysis of the main components of yield for grain and forage. Evaluated in 10 agronomic traits, two localities and three environments. Aguascalientes Ags. And Torreon Coahuila Mexico. 2007. (FY = forage yield, WS = stalk weight, WLP = plant leaves weight, WCL = corncob weight with its leaves, $\mathrm{PH}=$ plant height, GY = grain yield, $\mathrm{EL}=$ ear length, $\mathrm{ED}$ = diameter of cob, NGR = number of grain per row, NRE = number of rows per ear. Means with same letters are not statistic different (DMS, 0.05)).

\begin{tabular}{cccccccccccc}
\hline PARENTS & FY & WS & WLP & WCL & PH & GY & EL & ED & NGR & NRE \\
\hline M1 & $90.9 \mathrm{~B}$ & $42.1 \mathrm{~B}$ & $15.2 \mathrm{~B}$ & $33.4 \mathrm{~B}$ & $2.3 \mathrm{~B}$ & $7.8 \mathrm{C}$ & $18.6 \mathrm{~A}$ & $4.6 \mathrm{BC}$ & $37.5 \mathrm{BC}$ & $14.1 \mathrm{BC}$ \\
M2 & $82.8 \mathrm{BC}$ & $35.8 \mathrm{CD}$ & $14.6 \mathrm{~B}$ & $32.1 \mathrm{BC}$ & $2.0 \mathrm{C}$ & $7.7 \mathrm{C}$ & $19.5 \mathrm{~A}$ & $4.7 \mathrm{~B}$ & $38.0 \mathrm{AB}$ & $13.7 \mathrm{C}$ \\
M3 & $79.8 \mathrm{C}$ & $31.5 \mathrm{D}$ & $14.7 \mathrm{~B}$ & $28.7 \mathrm{C}$ & $2.0 \mathrm{C}$ & $9.3 \mathrm{~B}$ & $18.2 \mathrm{~A}$ & $4.6 \mathrm{BC}$ & $39.2 \mathrm{AB}$ & $14.4 \mathrm{~B}$ \\
M4 & $89.1 \mathrm{~B}$ & $38.2 \mathrm{BC}$ & $15.1 \mathrm{~B}$ & $35.7 \mathrm{AB}$ & $1.9 \mathrm{D}$ & $12.4 \mathrm{~A}$ & $19.0 \mathrm{~A}$ & $4.9 \mathrm{~A}$ & $38.9 \mathrm{AB}$ & $15.9 \mathrm{~A}$ \\
M5 & $87.0 \mathrm{BC}$ & $37.9 \mathrm{BC}$ & $14.6 \mathrm{~B}$ & $34.4 \mathrm{~B}$ & $2.1 \mathrm{C}$ & $11.6 \mathrm{~A}$ & $17.9 \mathrm{~A}$ & $4.7 \mathrm{~B}$ & $35.9 \mathrm{C}$ & $14.7 \mathrm{~B}$ \\
M6 & $106.2 \mathrm{~A}$ & $49.8 \mathrm{~A}$ & $18.2 \mathrm{~A}$ & $38.2 \mathrm{~A}$ & $2.4 \mathrm{~A}$ & $11.4 \mathrm{~A}$ & $19.3 \mathrm{~A}$ & $4.5 \mathrm{C}$ & $39.5 \mathrm{~A}$ & $14.4 \mathrm{~B}$ \\
\hline
\end{tabular}

with higher values for efficiency and its main components indicating uniformity in the behavior of these genotypes [19].

For the average of the top 15 crosses. The results of the mean values of the cross for all study variables, show the top 15 crosses based on forage yield and grain, same ranging between 123.0 and $98.4 \mathrm{t} \cdot \mathrm{ha}^{-1}$ for FY, and exceeded $89.36 \mathrm{t} \cdot \mathrm{ha}^{-1}$, and 14.49 to $7.87 \mathrm{t} \cdot \mathrm{ha}^{-1}$ for GY, where only 10 crosses exceeded the average 10.09 $\mathrm{kg} \cdot \mathrm{ha}^{-1}$, same as protrude in almost all variables. The crosses $6 \times 1$, presented the highest values in FY, GY and WCL with 123.0, 14.49 and $50.44 \mathrm{t}^{\mathrm{a}} \mathrm{a}^{-1}$, followed the $6 \times 3$ cross that was superior to the others in WS and WLP with 61.31 and $21.72 \mathrm{t}^{\mathrm{5}} \mathrm{ha}^{-1}$, furthermore, resulted in second place with $122.6 \mathrm{FY}$ and PH and $2.53 \mathrm{t} \cdot \mathrm{ha}^{-1}$. In the GY, the crosses $5 \times 1$ ranked second with $14.17 \mathrm{t} \cdot \mathrm{ha}^{-1}$. The high values of these crosses were due to the high degree of inbreeding of some lines and the effects it has on production (Table 3). The genetic diversity of the three groups of lines shows that combining contrasting characters, it crosses uniformity in all yield components, where there is the possibility that the recombination and selection combine some contrasting lines, heterotic patterns could be defined. The high-yielding hybrids, obtained performance not only of heterosis, but also hereditary factors as multiple interacting genes of additive type, so you must know the relative importance of genetic contribution in the production of hybrids [19].

General combining ability. The GCA effects (Table 4), show that the M6 resulted in values of 16.84 for FY, 
Table 3. Yield average of fresh forage and grain in $t \cdot \mathrm{ha}^{-1}$ from best 15 corn single cross for 10 agronomic characteristics evaluated, with North Caroline design I, in three environments with two localities, 2007. (FY = forage yield, WS = stalk weight, WLP = plant leaves weight, WCL = corncob weight with its leaves, $\mathrm{PH}=$ plant height, $\mathrm{GY}=$ grain yield, $\mathrm{EL}=$ ear length, $\mathrm{ED}$ = diameter of cob, NGR = number of grain per row, NRE = number of rows per ear. Means with same letters are not statistic different (DMS, 0.05)).

\begin{tabular}{|c|c|c|c|c|c|c|c|c|c|c|}
\hline CROSS & FY & WS & WLP & WCL & $\mathrm{PH}$ & GY & EL & ED & NGR & NRE \\
\hline $6 \mathrm{X} 1$ & $123.0 \mathrm{~A}$ & $52.97 \mathrm{D}$ & 19.63 B & $50.44 \mathrm{~A}$ & $2.42 \mathrm{~F}$ & $14.49 \mathrm{~A}$ & $20.98 \mathrm{C}$ & $4.63 \mathrm{G}$ & $37 \mathrm{~J}$ & 13.92 I \\
\hline $6 \times 3$ & 122.6 B & $61.31 \mathrm{~A}$ & $21.72 \mathrm{~A}$ & $39.66 \mathrm{G}$ & $2.53 \mathrm{~B}$ & $10.26 \mathrm{~J}$ & $19.55 \mathrm{H}$ & $4.42 \mathrm{~J}$ & $37.67 \mathrm{H}$ & $13.15 \mathrm{~K}$ \\
\hline $6 \mathrm{X} 2$ & $114.3 \mathrm{C}$ & $53.80 \mathrm{C}$ & $17.80 \mathrm{G}$ & $42.75 \mathrm{~B}$ & $2.14 \mathrm{~K}$ & $10.86 \mathrm{H}$ & $20.27 \mathrm{~F}$ & $4.8 \mathrm{~B}$ & 43.17 B & $16.52 \mathrm{~B}$ \\
\hline $6 \times 8$ & $113.8 \mathrm{D}$ & 54.07 B & 19.47 C & $40.30 \mathrm{~F}$ & $2.39 \mathrm{G}$ & $10.96 \mathrm{G}$ & $17.87 \mathrm{~N}$ & $6.78 \mathrm{C}$ & $42.33 \mathrm{D}$ & $14.12 \mathrm{G}$ \\
\hline $1 \mathrm{X} 2$ & $111.2 \mathrm{E}$ & $52.94 \mathrm{E}$ & $17.63 \mathrm{I}$ & $41.07 \mathrm{E}$ & $2.52 \mathrm{C}$ & $7.89 \mathrm{~N}$ & 21.77 B & $4.7 \mathrm{E}$ & 38.17 G & $16.43 \mathrm{C}$ \\
\hline $6 \times 11$ & $105.7 \mathrm{~F}$ & $51.07 \mathrm{~F}$ & $17.33 \mathrm{~K}$ & $37.30 \mathrm{~K}$ & $2.49 \mathrm{D}$ & $11.26 \mathrm{~F}$ & $20.53 \mathrm{E}$ & 4.52 I & $43 \mathrm{C}$ & $14 \mathrm{H}$ \\
\hline $6 \mathrm{X} 4$ & $105.7 \mathrm{~F}$ & $50.70 \mathrm{H}$ & $18.28 \mathrm{E}$ & $36.69 \mathrm{M}$ & $2.59 \mathrm{~A}$ & 10.57 I & $19.82 \mathrm{G}$ & $2.28 \mathrm{~K}$ & $36 \mathrm{~L}$ & 13.92 I \\
\hline $6 X 6$ & 105.5 G & $50.03 \mathrm{~J}$ & $18.58 \mathrm{D}$ & $36.84 \mathrm{~L}$ & $2.39 \mathrm{G}$ & $11.37 \mathrm{E}$ & $18.95 \mathrm{~L}$ & $4.6 \mathrm{I}$ & $40 \mathrm{~F}$ & $14.27 \mathrm{~F}$ \\
\hline $1 \mathrm{X} 5$ & $104.2 \mathrm{H}$ & $49.64 \mathrm{~K}$ & $15.69 \mathrm{~N}$ & 38.84 I & $2.17 \mathrm{~J}$ & $8.58 \mathrm{M}$ & $20.78 \mathrm{D}$ & $4.78 \mathrm{C}$ & $36.5 \mathrm{~K}$ & $14.27 \mathrm{~F}$ \\
\hline $1 \mathrm{X} 8$ & 102.2 I & $51.04 \mathrm{G}$ & $15.91 \mathrm{M}$ & $35.21 \mathrm{~N}$ & $2.43 \mathrm{E}$ & $9.30 \mathrm{~L}$ & $18.27 \mathrm{M}$ & $4.8 \mathrm{~B}$ & $40.33 \mathrm{E}$ & $13.07 \mathrm{~L}$ \\
\hline $5 \mathrm{X} 1$ & $101.4 \mathrm{~J}$ & $42.11 \mathrm{~N}$ & $17.66 \mathrm{H}$ & $41.58 \mathrm{D}$ & $2.18 \mathrm{I}$ & 14.17 B & $21.78 \mathrm{~A}$ & $4.67 \mathrm{~F}$ & 37.17 I & $15.1 \mathrm{D}$ \\
\hline $1 \mathrm{X} 9$ & $101.0 \mathrm{~K}$ & $50.25 \mathrm{I}$ & $18.09 \mathrm{~F}$ & $35.68 \mathrm{O}$ & $2.42 \mathrm{~F}$ & $9.35 \mathrm{~K}$ & $19.25 \mathrm{~J}$ & $4.62 \mathrm{H}$ & $43 \mathrm{C}$ & $14.4 \mathrm{E}$ \\
\hline $2 \times 2$ & $99.6 \mathrm{~L}$ & $45.49 \mathrm{~L}$ & $16.14 \mathrm{~L}$ & $37.96 \mathrm{~J}$ & $2.17 \mathrm{~J}$ & $7.98 \mathrm{~N}$ & $19.17 \mathrm{~K}$ & $4.75 \mathrm{D}$ & $44.5 \mathrm{~A}$ & $13.48 \mathrm{~J}$ \\
\hline $5 \times 9$ & $99.6 \mathrm{~L}$ & $42.52 \mathrm{M}$ & $17.54 \mathrm{~J}$ & $39.53 \mathrm{H}$ & $2.27 \mathrm{H}$ & $11.56 \mathrm{D}$ & $17.52 \mathrm{O}$ & $4.8 \mathrm{C}$ & $34.5 \mathrm{M}$ & $14.47 \mathrm{M}$ \\
\hline $4 \mathrm{X} 1$ & $98.4 \mathrm{M}$ & $40.04 \mathrm{~N}$ & $16.14 \mathrm{~L}$ & $42.22 \mathrm{C}$ & $1.99 \mathrm{~L}$ & $13.29 \mathrm{C}$ & $19.52 \mathrm{I}$ & $4.85 \mathrm{~B}$ & $37.0 \mathrm{~J}$ & $16.87 \mathrm{~A}$ \\
\hline
\end{tabular}

Table 4. Estimated General Combining Ability Values (GCA) of Corn Lines used as Males in two Locations and Three Environments. Aguascalientes Ags, and Torreon Coah. 2007. (FY = forage yield, WS = stalk weight, WLP = plant leaves weight, WCL = corncob weight with its leaves, $\mathrm{PH}=$ plant high, $\mathrm{GY}=$ grain yield, $\mathrm{EL}=$ ear length, $\mathrm{ED}=$ diameter of ear, $\mathrm{NGR}=$ number of grain per row, NRE $=$ number of rows per ear. $\left.{ }^{*}=(\mathrm{p} \leq 0.05),{ }^{* *}=(\mathrm{p} \leq 0.01)\right)$.

\begin{tabular}{cccccccccccc}
\hline PARENTS & FY & WS & WLP & WCL & PH & GY & EL & ED & NGR & NRE \\
\hline M1 & 1.54 & 2.9 & -0.24 & -0.3 & 0.15 & -2.29 & -0.18 & -0.1 & -0.71 & -0.47 \\
M2 & -6.56 & -3.4 & -0.84 & -1.6 & -0.15 & -2.39 & 0.72 & 0 & -0.21 & -0.87 \\
M3 & -9.56 & -7.7 & -0.74 & -5 & -0.15 & -0.79 & -0.58 & -0.1 & 0.99 & -0.17 \\
M4 & -0.26 & -1 & -0.34 & 2 & -0.25 & 2.31 & 0.22 & 0.2 & 0.69 & 1.33 \\
M5 & -2.36 & -1.3 & -0.84 & 0.7 & -0.05 & 1.51 & -0.88 & 0 & -2.31 & 0.13 \\
M6 & 16.84 & 10.6 & 2.76 & 4.5 & 0.25 & 1.31 & 0.52 & -0.2 & 1.29 & -0.17 \\
DMS $_{(0.05)}$ & 27.06 & 14.77 & 4.34 & 11.19 & 0.12 & 4.34 & 6.35 & 0.36 & 27.06 & 14.77 \\
\hline
\end{tabular}

and $1.31 \mathrm{t}^{\mathrm{tha}} \mathrm{H}^{-1}$ for RY, along with 10.6, 2.76, 4.5, 0.25 and 1.29 for WS, WLP, WCL, PH and NGR respectively. The M4 was above all in GY, ED and NRE values of 2.31, 0.2 and 1.33 respectively. The maleM1ranked second in the FY, WS and PH variables with values of 1.54, 2.9 and $0.15 \mathrm{~m}$, while M5 ranked second in the GY and

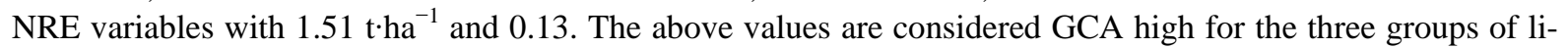
nesas [20]. According to the observed values, specific combinations where the M6, M1 and M4 male female involved with H1, H2, H3 and H8 lines are observed, so these lines should be considered as potential female progenitors to form hybrids with lines male progenitor UAAANUL and INIFAP. Some researchers have confirmed the genetic potential of these lines with previous work, indicating their genetic merit in hybrid combinations. 
GCA values presented by these male and female parents had a greater contribution to the phenotypic expression, consistent with the findings of [8]. With these sequential results and according to the characteristics studied, there may be favorable for improving the performance [21] results. When crossing corn inbred lines to study combinatorial types of skills, behaviors and values depend on the genetic makeup of each parent and the diversity of their origin [22].

The effects of specific combining ability. These are presented in (Table 5), where it was observed that among the 15 best crosses in FY, there were $4 \times 8,4 \times 4,4 \times 4$ and $5 \times 5$ with 17.56, 16.56, 14.06 and 14.06 $\mathrm{t} \cdot \mathrm{ha}^{-1}$, respectively, while for GY were $3 \times 10,6 \times 10$ and $6 \times 1$ with $1.94,1.78$ and $1.26 \mathrm{t} \cdot \mathrm{ha}^{-1}$, were the highest positive values of SCA for yield andits main components. In general it was found that lines with low values of GCA formed crosses within creased expression of SCA and performance, coinciding with [23]. Therefore, it is feasible to identify the best combinations of lines and hybrids in high productivity(for GCA), test and selectonly hybrids combinations where high values of SCA is expressed, even if the low GCA has been the most important for the identification of lines [24].

The contribution to the variation among the crosses for most of the traits, is attributable to the non-additive interaction effects Male xFemale (MxH) as SCA values were higher than those of GCA, coinciding with that reported by [25], who found higher values for SCA than for GCA, however, [26] reported significant differences for both sources of variation GCA and SCA. Must also be analyzed for forage quality corn, stems, leaves and pods stem of each leaf, to maximize and complement the research advances in forage maize, where the increase of performance, quality plant and grain is considered [27]. [28] finds that the GCA lines, is the source of most important characteristics of corn forage yield variation, which reinforces the idea of selecting for yield and forage quality. In this work, some were superior hybrids in the future could be commercially exploited, such as crosses, $4 \times 8,4 \times 3,4 \times 4$ and $5 \times 5$, so it is necessary to plant them in demonstration plots for farmers to identify them and compare them to hybrids they plant.

Heterosis based on the average parent. For heterosis based on the average parent in FY ranged from 8.0 to

Table 5. Specific Combining Ability (SCA) from best 15 corn single cross for 10 agronomic characteristics evaluated, with North Caroline design I, in three environments with two localities, 2007. (FY = fresh forage yield, WS = stalk weight, WLP = plant leaves weight, WCL = corncob weight with its leaves, $\mathrm{PH}=$ plant height, GY = grain yield, EL = ear length, ED = diameter of ear, NGR = number of grain per row, NRE = number of rows per ear. $\left.{ }^{*}=(\mathrm{p} \leq 0.05),{ }^{* *}=(\mathrm{p} \leq 0.01)\right)$.

\begin{tabular}{|c|c|c|c|c|c|c|c|c|c|c|}
\hline CROSS & FY & WS & WLP & WCL & $\mathrm{PH}$ & GY & EL & ED & NGR & NRE \\
\hline $6 \mathrm{X} 1$ & 6.96 & -0.33 & 0.07 & 6.34 & -0.02 & 1.78 & -0.24 & 0.2 & -1.29 & -0.51 \\
\hline $6 \times 3$ & 9.56 & 7.81 & 2.36 & -0.94 & 0.18 & 0.15 & 1.43 & 0.07 & -1.22 & -1.18 \\
\hline $6 \times 2$ & 5.36 & 1.4 & -0.86 & 3.95 & -0.23 & -0.15 & 0.55 & 0.3 & 0.58 & 1.99 \\
\hline $6 \times 8$ & 7.66 & 3.87 & 2.01 & 3.6 & -0.07 & -1.25 & 0.05 & 2.15 & -0.16 & 0.09 \\
\hline $1 \mathrm{X} 2$ & 17.56 & 8.24 & 1.97 & 7.07 & 0.25 & 0.48 & 2.75 & 0.1 & -2.42 & 2.2 \\
\hline $6 \times 11$ & -0.64 & 2.07 & -0.33 & -1.2 & 0.07 & 0.7 & 2.01 & 0.07 & 3.21 & 0.27 \\
\hline $6 \times 4$ & 6.76 & 3.2 & 2.02 & 1.19 & 0.22 & -0.34 & 0.9 & -2.14 & -0.99 & -0.01 \\
\hline $6 \times 6$ & 3.06 & 1.83 & 0.12 & 0.24 & 0.02 & 0.06 & 1.03 & 0.03 & 0.91 & 0.14 \\
\hline $1 \times 5$ & 11.16 & 6.04 & 0.03 & 4.44 & -0.09 & 0.77 & 1.86 & 0.09 & -1.09 & -0.16 \\
\hline $1 \mathrm{X} 8$ & 11.36 & 8.54 & 1.45 & 3.31 & 0.07 & 0.69 & 1.15 & 0.07 & -0.16 & -0.66 \\
\hline $5 \times 1$ & 4.56 & 0.71 & 1.7 & 1.28 & 0.04 & 1.26 & 1.96 & 0.04 & 2.48 & 0.37 \\
\hline $1 \mathrm{X} 9$ & 11.56 & 8.05 & 2.83 & 2.88 & 1.07 & 1.94 & -2.77 & 0.01 & 4.61 & 0.37 \\
\hline $2 \times 2$ & 14.06 & 7.09 & 1.08 & 5.26 & 0.2 & 0.67 & -0.75 & 0.05 & 3.41 & -0.35 \\
\hline $5 \times 9$ & 14.06 & 4.52 & 2.88 & 5.73 & 1.12 & 0.35 & -3.8 & 0.09 & -2.29 & -0.16 \\
\hline $4 \mathrm{X} 1$ & 16.56 & -1.66 & -0.32 & 0.62 & 0.05 & -0.42 & -1.4 & 0.02 & -0.69 & 0.94 \\
\hline $\operatorname{DMS}_{(0.05)}$ & 22.56 & 12.16 & 3.3 & 10.98 & 0.09 & 2.13 & 3.43 & 0.09 & 4.56 & 1.34 \\
\hline
\end{tabular}


21.5\%, all exceeding the average parent in the 15 crosses, all were positive heterosis, which excel $1 \times 2,6 \times 3$ and $6 \times 1$ cross, with values of $21.5 \%, 21.1 \%$ and $20.2 \%$ respectively (Table 6). To FY values ranged from -9.8 to $27.1 \%, 6 \times 1$ and $5 \times 1$ crosses the highest values obtained with $27.1 \%$ and $23.2 \%$. These values are lower than the heterosis of $132.8 \%$ and $38.9 \%$ reported some of these lines [6]. In the cross $6 \times 1(27.1 \%), 5 \times 1$ (23.2\%) and $4 \times 1$ (11.6\%) were the highest for GY, intervened H1, and this same cross to FY resulted the cross best third (20.2\%) and resulted in a very low value in the $5 \times 1$ with (8.9\%), given the above, this cross, participated with the highest and lowest heterosis. These results suggest in RG that between M1 and H2 lines no heterosis, which reflects genetic divergence of both genotypes, indicating common loci for grain yield. All crosses where intervened $\mathrm{H} 2$, have low or negative heterosis levels, which may be due to the high yield potential of this line. In this regard, [29] mention that the expression of heterosis is an indicator of genetic divergence, but the absence of it does not

Heterosis based on superior parent. The heterosis with respect to superior parent is presented in (Table 7). FY is noted that the maximum and minimum value of heterosis was $20.7 \%$ to $-0.6 \%$ corresponding to the $1 \times 2$ and $6 \times 6$, respectively crosses. Of the 15 best crosses, three (20\%) had negative effects on this variable, while $12(80 \%)$ remaining, showed positive effects of heterosis. For the GY, the values ranged from -18.6 to $27.1 \%$ for $1 \times 2$ and $6 \times 1$ respectively crosses, three crosses (20\%) were positive and $12(80 \%)$ remaining, had negative effects. In populations of maize, the desired level for the use of heterosis in crosses is at least $20 \%$ [6]. In this work highlights the crosses $1 \times 2(20.7 \%), 6 \times 1(27.1 \%)$, and $5 \times 1(22.1 \%)$ in terms of forage yield and grain, indicating that there is genetic diversity among parents, since heterosis exhibited in their crosses depends on the yielder fitness and genetic diversity of the parents used. It can be seenthat M1, participated in crosses of goodwill and negative heterosis due to the high yield potential of that parent. The $6 \times 1$ crosses on grain yield $\left(14.49 \mathrm{t}^{\mathrm{h}} \mathrm{h}^{-1}\right)$, showed the highest value of heterosis (27.1\%) and effect of SCA of $1.78 \mathrm{t} \cdot \mathrm{ha}^{-1}$, followed by $5 \times 1$ with (14.17 $\mathrm{t}^{-h^{-1}}{ }^{-1}$ ), showed the second highest value of heterosis (22.1\%) and SCA, $1.26 \mathrm{t} \cdot \mathrm{ha} \mathrm{h}^{-1}$. For FY $1 \times 2$ crosses with yield of $111.2 \mathrm{t} \cdot \mathrm{ha}^{-1}$, showed the highest heterosis effect (20.7\%) and effect of SCA $17.56 \mathrm{t} \cdot \mathrm{ha}^{-1}$. These crosses could have the potential to be used as commercial hybrids.

Table 6. Heterosis based on the average parent(h), for the main components of yield their direct crosses. Combine two localities and three environments, Torreon Coahuila and Aguascalientes Ags. Mexico, 2007.

\begin{tabular}{|c|c|c|c|c|c|c|c|c|c|c|}
\hline \multirow{2}{*}{ CROSS } & FY & WS & WLP & WCL & $\mathrm{PH}$ & GY & EL & ED & NGR & NRE \\
\hline & $\mathrm{h}$ & $\mathrm{h}$ & $\mathrm{h}$ & $\mathrm{h}$ & h & $\mathrm{h}$ & $\mathrm{h}$ & $\mathrm{h}$ & $\mathrm{h}$ & $\mathrm{h}$ \\
\hline $6 \mathrm{X} 1$ & 20.2 & 14.5 & 12.1 & 29.6 & 5.4 & 27.1 & 4.9 & 1.4 & -3.2 & -4.0 \\
\hline $6 \times 3$ & 21.1 & 32.2 & 24.8 & 6.7 & 12.4 & 1.5 & 5.9 & -2.3 & -2.2 & -8.9 \\
\hline $6 \times 2$ & 15.2 & 17.4 & 4.3 & 17.9 & -5.3 & 2.9 & 5.2 & 4.3 & 6.8 & 13.5 \\
\hline $6 \times 8$ & 16.4 & 20.9 & 18.3 & 14.4 & 3.6 & -1.7 & -2.3 & 45.3 & 4.9 & -1.2 \\
\hline $1 \mathrm{X} 2$ & 21.5 & 26.1 & 13.3 & 21.3 & 14.0 & -9.8 & 15.1 & 1.0 & -3.1 & 14.0 \\
\hline $6 X 11$ & 8.0 & 15.8 & 4.7 & 3.3 & 8.9 & 9.0 & 10.0 & -1.2 & 10.2 & -1.0 \\
\hline $6 \times 4$ & 12.2 & 16.9 & 15.3 & 6.0 & 14.6 & 0.6 & 5.1 & -50.0 & -4.2 & -2.3 \\
\hline $6 \times 6$ & 10.0 & 14.4 & 9.6 & 4.8 & 5.7 & 6.2 & 3.2 & -0.7 & 3.4 & -0.5 \\
\hline $1 \mathrm{X} 5$ & 14.2 & 19.9 & 0.9 & 14.0 & -1.5 & -4.1 & 10.2 & 1.8 & -3.6 & -1.5 \\
\hline $1 \mathrm{X} 8$ & 13.4 & 24.9 & 6.4 & 7.3 & 7.7 & -0.5 & 1.7 & 1.8 & 2.4 & -7.6 \\
\hline $5 \mathrm{X} 1$ & 8.9 & 4.4 & 12.4 & 12.3 & 1.6 & 23.2 & 12.8 & 0.1 & 1.9 & 3.0 \\
\hline $1 \mathrm{X} 9$ & 12.9 & 23.4 & 17.8 & 7.3 & 38.2 & 6.8 & -5.6 & -0.7 & 12.2 & 0.6 \\
\hline $2 X 2$ & 13.8 & 17.2 & 5.8 & 14.3 & 5.3 & -8.2 & -0.9 & 1.0 & 12.2 & -5.0 \\
\hline $5 \times 9$ & 13.8 & 10.1 & 16.5 & 17.1 & 37.5 & 8.5 & -12.6 & 2.0 & -8.0 & -0.8 \\
\hline $4 \mathrm{X} 1$ & 14.9 & -1.0 & 1.1 & 12.1 & -2.6 & 11.6 & -1.6 & 1.7 & -2.5 & 10.6 \\
\hline
\end{tabular}


Table 7. Heterosis based on betterparent (h'), for the main components of the yields their direct crosses. Combine two localities and three environments, Torreon Coahuila and Aguascalientes Ags. Mexico, 2007.

\begin{tabular}{|c|c|c|c|c|c|c|c|c|c|c|}
\hline \multirow{2}{*}{ CROSS } & FY & WS & WLP & WCL & $\mathrm{PH}$ & GY & EL & ED & NGR & NRE \\
\hline & h' & h' & h' & h' & h' & h' & h' & h' & h' & h' \\
\hline $6 \mathrm{X} 1$ & 15.8 & 6.3 & 7.8 & 27.3 & 10.5 & 27.1 & 1.3 & 0.0 & -6.3 & -4.6 \\
\hline $6 \times 3$ & 15.4 & 23.1 & 19.3 & 3.8 & 5.4 & -10.0 & 1.2 & -2.8 & -4.6 & -9.3 \\
\hline $6 \times 2$ & 7.6 & 8.0 & -2.1 & 11.9 & 0.9 & -4.7 & 5.0 & 2.1 & 4.5 & 12.3 \\
\hline $6 \times 8$ & 7.1 & 8.5 & 6.9 & 5.4 & 8.1 & -3.8 & -7.4 & 40.3 & 2.7 & -1.9 \\
\hline $1 \mathrm{X} 2$ & 20.7 & 25.7 & 10.8 & 19.7 & 18.8 & -18.6 & 13.3 & 0.0 & -7.5 & 11.7 \\
\hline $6 X 11$ & -0.4 & 2.5 & -4.7 & -2.3 & 14.7 & -1.2 & 6.3 & -2.7 & 8.8 & -2.7 \\
\hline $6 \mathrm{X} 4$ & -0.4 & 1.8 & 0.4 & -3.9 & 22.1 & -7.2 & 2.6 & -50.6 & -8.8 & -3.3 \\
\hline $6 \times 6$ & -0.6 & 0.4 & 2.0 & -3.5 & 12 & -0.2 & -1.8 & -3.5 & 1.2 & -0.9 \\
\hline $1 \mathrm{X} 5$ & 13.8 & 17.9 & -1.3 & 11.9 & 2.8 & -15.0 & 8.7 & -0.2 & -4.6 & -4.2 \\
\hline $1 \mathrm{X} 8$ & 12.4 & 21.2 & 4.6 & 5.4 & 9.9 & -14.6 & -1.7 & -0.6 & -2.1 & -7.9 \\
\hline $5 \mathrm{X} 1$ & 2.2 & -1.3 & 5.1 & 5.0 & -0.4 & 22.1 & 5.2 & -0.6 & 0.4 & 2.7 \\
\hline $1 \mathrm{X} 9$ & 11.1 & 19.3 & 16.7 & 6.8 & 5.2 & -3.6 & -13.2 & -1.9 & 9.9 & -0.6 \\
\hline $2 X 2$ & 8.1 & 8.8 & 1.5 & 10.6 & 2.3 & -17.7 & -1.6 & 1.0 & 7.7 & -8.2 \\
\hline $5 \times 9$ & 13.3 & 8.1 & 13.1 & 14.9 & 8.0 & -0.3 & -21.0 & 1.9 & -11.7 & -1.5 \\
\hline $4 \mathrm{X} 1$ & 10.4 & -6.2 & -3.9 & 6.6 & -9.1 & 7.1 & -5.7 & 4.7 & -4.8 & 6.1 \\
\hline
\end{tabular}

\section{Discussion}

In the combined analysis of variance significant deference to the source of variation males were detected in all variables except for ear length, indicating that there were environmental differences, climate and soil mainly in different localities. However, for the crosses only features ear length, ear diameter, number of kernels per row, plant height and number of rows per ear, were significant, indicating that they were the most sensitive to environmental changes, this shows the importance of evaluation in a larger number of environments, because in this way a better estimation of genetic effects will be estimated. The coefficients of variation (less than 21.57\%) were higher than those obtained by [30], and similar to those obtained by [11], because of the genetic diversity in the three groups of lines. The mean squares of GCA effects across males were larger in magnitude than the mean squares of the SCA through their crosses for forage yield and grain, suggesting that the largest proportion of genetic variability it was observed, associated with additive effects, as indicated [31]. While the effects of SCA were greater for the variable ear length, indicating a genetic control no additive variance for this character [5].

According to the comparison of means for parents and their crosses for FY, only two parents showed higher yields than the overall mean $\left(89.36 \mathrm{t} \cdot \mathrm{ha}^{-1}\right)$, while the top 15 cross the it exceeded, while for GY three parents were higher than the overall average $\left(10.09 \mathrm{t} \cdot \mathrm{ha}^{-1}\right)$ and a 10 crosses the beat, this reflects the high yield potential of $6 \times 1,6 \times 3,5 \times 1$ and $4 \times 1$ cross, and the potential of lines M6, M1 and M4 for a program of genetic improvement of maize for grain and forage yield.

According to the results of GCA, were significant effect $(p \leq 0.01)$ in almost all variables, which indicates that they were of greater magnitude than the mean squares of SCA. This response suggests that the largest proportion of genetic variability observed in the parental lines was associated with additive effects, which highlights and indicates the expression that yield control, the additive effects were the most important in these three groups of lines studied, as indicated [17]. For the yield of green fodder, parent M6 (B-40) resulted in the highest value, while for grain yield, the GCA highest value was for M4 parent (AN-388R). These results suggest that these groups of lines have a high contribution in the expression of their respective progeny performance and the 
effects of the additive type are important. Regard, [32] noted that the detected major effects of general combining ability, it is feasible to exploit the proportion of additive genetic variance available through any variant of recurrent selection.

On the effects of SCA, for forage yield, $6 \times 11$ crosses showed negative effects significantly different from zero, what it means, that cross was less than what would be expected based on the GCA of parental behavior. By contrast the $1 \times 2,4 \times 1,2 \times 2$ and $5 \times 9$ cross presented positive effects SCA and significantly different from zero $(\mathrm{p} \leq 0.01)$ in grain yield, crosses $1 \times 9,6 \times 1$ and $5 \times 1$ different positive effects presented zero. All this suggests that non-additive gene action is involved in the crosses mentioned and that performance can be increased by hybridization. Is interesting to note, that M4, M2 and M5 parents showed negative GCA effects, resulted in three $(4 \times 1,2 \times 2$ and $5 \times 9)$ from crosses with positive effects of SCA and significantly different from zero ( $\mathrm{p} \leq 0.01$ and $\mathrm{p} \leq 0.05$ ). In this regard, it was expected that most SCA crosses, have been those resulting from crossing at least one population with high GCA [33]. But not necessarily the lines with high GCA produced promising crosses for grain yield. Similar results were obtained by [34], across germplasm negative GCA effects and get high and positive values of SCA in crosses.

From the point of view of gene identification purposes used inbreeding programs, GCA effects should be considered so as SCA, depending on specific objectives [35]. So the M1, M4 and M6 parents based on GCA effects could be included in a breeding program for synthetic varieties. Also crosses identified with the greatest effects of SCA could be considered in a breeding program for hybrid formation. With regard to the negative effects of heterosis estimates in this paper, also [36] reported similar values for tropical maize populations. As for the positive values of heterosis, those found in the present study were higher than those found by [6] with some of these same parents, which shows the yielder fitness and genetic diversity of these parents used [37]. Regard [22] showed that across maize inbred lines to study the types of combinatorial skills, behaviors and values depend on the genetic makeup of each parent and the diversity of origin. According to [38] [39], the larger hybrid vigor due to the presence in the zygote of a larger number of key genes in the parents, for joining the dominant genes provided by them, to be expressed in this manner, the effects of heterosis in the progeny.

\section{Conclusion}

The yield off or age decreased between 7 and 8.5 times in weight of forage to grain weight in the best crosses. Additive effects were the main component in the expression off or age and grain yield of the studied lines. The highest GCA effects were detected in the M6 and M4 male parents, while $1 \times 2,4 \times 1,1 \times 9$ and $6 \times 1$, crosses showed the greatest effects of SCA. The lines with the highest GCA effects can be included in a breeding program for synthetic varieties. And the crosses with the greatest effects of SCA may be considered in a breeding program for hybrid formation in a short time. These results indicate that in a short time, we can obtain new commercial hybrids, which can be planted in north central Mexico.

\section{References}

[1] Gutiérrez del Río, E., Espinoza Banda, A., Palomo Gíl, A., Lozano Gracia, J. and Antuna Grijalv, O. (2004) Aptitud Combinatoria de Híbridos de Maíz para la Comarca Lagunera. Revista Fitotecnia Mexicana 27, Núm. Especial 1, 7-11.

[2] Castañón-Nájera, G., Latournerie-Moreno, L. and Mendoza-Elos, M. (2005) Macro de SAS-IML para Analizar los Diseños II y IV de Griffing. Universidad y Ciencia, 21, 27-35.

[3] Vasal, S.K., Srinivasan, G.F., González, C., Beck, D.L. and Crossa, J. (1993) Heterosis and Combining Ability of CIMMYT’s Quality Protein Maize Germplasm: II. Subtropical. Crop Science, 33, 51-57. http://dx.doi.org/10.2135/cropsci1993.0011183X003300010007x

[4] Comstock, R.E. and Robinson, H.F. (1948) The Components of Genetic Variance in Populations of Biparental Progenies.

[5] Márquez, S.F. (1988) Geotecnia Vegetal. Tomo III. Primera Edición. Editor AGT. México, 536.

[6] Gutiérrez del R., E., Palomo, A., Espinoza, A. and De La Cruz, E. (2002) Aptitud Combinatoria y Heterosis Para Rendimiento De Líneas De Maíz De La Comarca Lagunera, México. Revista Fitotecnia Mexicana, 25, 271-277.

[7] Malik, H.N., Malik, S., Chughtai, S.R. and Javed, H.I. (2004) Estimates of Heterosis among Temperate, Subtropical and Tropical Maize Germplasm. Asian Journal of Plant Sciences, 3, 6-10. http://dx.doi.org/10.3923/ajps.2004.6.10

[8] De La Cruz, L.E.E., Gutiérrez del, R., Palomo, A. and Rodríguez, S. (2003) Aptitud Combinatoria y Heterosis de Líneas de Maíz de la Comarca Lagunera. Revista Fitotecnia Mexicana, 26, 279-284. 
[9] De León-Castillo, H., De La Rosa-Loera, A., Rincón Sánchez, F. and Martínez-Sambrano, G. (2006) Efectos Genéticos, Heterosis y Diversidad Genética Entre Híbridos Comerciales de Maíz Adaptados al Bajío Mexicano. Revista Fitotecnia Mexicana., 29, 247-254.

[10] Antuna-Grijalva, O., Bustamante-García, L., Gutiérrez-Del Rio, E., Rincón-Sánchez, F. and Ruiz-Torres, N.A. (2003) Componentes de Caracteres Agronómicos y de Calidad Fisiológica de Semillas de Líneas de Maíz. Revista Fitotecnia Mexicana, 26, 11-17.

[11] Wong-Romero, R., Gutiérrez-Del Rio, E., Rodríguez-Herrera, S., Palomo-Gil, A., Córdoba-Orellana, H. and EspinozaBanda, A. (2006) Aptitud Combinatoria y Parámetros Genéticos de Maíz para Forraje en La Comarca Lagunera. Universidad y Ciencia, 22, 141-151.

[12] Clark, P.W., Keelm, S. and Enres, M.I. (2002) Effect off Feeding a Corn Hybrid Selected for Leafinss as Silage or Grain to Lactacting Dairy Cattle. Journal of Dairy Science, 85, 607-612. http://dx.doi.org/10.3168/jds.S0022-0302(02)74114-3

[13] Reta, S.D.G., Gaitán, M.A. and Carrillo, A.J. (2002) Respuesta del Maíz para Ensilaje a Metros de Siembra y Densidad de Población. Revista Fitotecnia Mexicana, 23, 37-48.

[14] Instituto Nacional de Geografía y Estadística (INEGI) (2008) Atlas Nacional Interactivo de México. (en línea). Estado de Coahuila. Estado de Aguascalientes. Consultado 16 de mayo 2010. http://inegi.org.mx

[15] Centro Internacional del Mejoramiento de Maíz y Trigo (MMYT) (1999) Maize Inbred Lines Relased by CIMMYT. A Compilation of 424 CIMMYT Maize Lines (CMLs). First draft. México,D.F.56 p.

[16] Statistical Analysis System (SAS) (1988) User’s Guide. Versión 6.11. SAS Institute Inc. Caray, N.C.,USA.

[17] Guillen-de la Cruz, P., de la Cruz-Lázaro, E., Castañon-Najera, G., Osorio-Osorio, R., Brito-Manzano, N.P., Lozanodel Río, A. and López-Noverola, U. (2009) Aptitud Combinatoria General y Especifica de Germoplasma Tropical de Maíz. Tropical and Subtropical Agroecosystems, 10, 101-107.

[18] Wong-Romero, R., Gutiérrez-Del Rio, E., Lozano-García, J., Palomo-Gil, A. and Rodríguez-Herrera, S. (2007) Aptitud Combinatoria de Componentes del Rendimiento en Líneas de Maíz para Grano en la Comarca Lagunera, México. Revista Fitotecnia Mexicana, 30, 181-189.

[19] López, L.M. (2003) El cultivo de Maíz en México y la Contribución del Fitomejorador para Favorecer la Autosuficiencia. Universidad Laguna. México. Revista Mexicana de Agronegocios, 12, 596-605.

[20] Vergara, A.N., Rodríguez, H.S. and Córdova, O.H.S. (2005) Aptitud Combinatoria General y Especifica de Líneas de Maíz (Zea mays) Tropical y Subtropical. Agronomía Mesoamericana, 16, 137-143.

[21] Márquez, S.F. (1991) Geotecnia Vegetal. Métodos y Teoría. Tomo III. AGT Editor. S.A. México, D.F.500 p.

[22] Sprague, G.F. and Tatum, L.A. (1942) General vs Specific Combining Ability in Single Crosses of Corn. Journal American Society Agronomy, 34, 923-932.

[23] De la Cruz-Lázaro, E., Córdova-Orellana, H., Estrada-Botello, M.A., Mendoza-Palacios, J.D., Gómez-Vásquez, A. and Brito Manzano, N.P. (2009) Rendimiento de Grano de Genotipo de Maíz Sembrados Bajo tres Densidades de Población. Universidad y Ciencia, 25, 93-98.

[24] Hallauer, R.A. and Miranda, F.O. (1988) Quantitative Genetics in Maize Breeding. The lowa state University Press Ames, lowa, 468.

[25] De la Cruz-Lázaro, E., Rodríguez-Herrera, S., Estrada-Botello, M.A., Mendoza-Palacios, J.D. and Brito-Manzano, N.P. (2005) Análisis Dialelico de Líneas de Maíz QPM para Características Forrajeras. Universidad y Ciencia, 21, 19-26.

[26] De la Rosa, A., De León, H., Martínez, G. and Rincón, F. (2000) Heterosis, Habilidad Combinatoria y Diversidad Genética en Híbridos Comerciales de maíZ. Agronomía Mesoamericana, 11, 113-122.

[27] Moreno, G.J., Martinez, I., Brichette, I., Lopez, A. and Castro, P. (2000) Breeding Potential of European Flint and U.S. Corn Belt Dent Maize Populations for Forage Use. Crop Science, 40, 1588-1595. http://dx.doi.org/10.2135/cropsci2000.4061588x

[28] Argillier, O., Mèchin, V. and Barriere, Y. (2000) Inbred Line Evaluation and Breeding for Silage and NIRS Traits in a Forage Maize. Crop Science, 40, 1596-1600. http://dx.doi.org/10.2135/cropsci2000.4061596x

[29] De la Cruz-Lázaro, E., Castañón-Nájera, G., Brito-Manzano, N.P., Gómez-Vázquez, A., Robledo-Torres, V. and Lozano-Del Río, A.J. (2010) Heterosis y Aptitud Combinatoria de Poblaciones de Maíz Tropical. Revista Phyton. Argentina, 79, 11-17.

[30] De la Cruz-Lázaro, E., Rodríguez-Herrera, S., Estrada-Botello, M.A., Mendoza-Palacios, J.D. and Brito-Manzano, N.P. (2007) Análisis Dialélico de Líneas de Maíz QPM para Características Forrajeras. Universidad y Ciencia, 21, 19-26.

[31] Barriere, Y., Hebert, Y., Julier, B., Young, E. and Furstoss, V. (1993) Genetic Variation for Silage and NIRS Traits in a Half-Diallel Design of 21 Inbred Lines of Maize. Maydica, 38, 7-13.

[32] Preciado E., O.R. Terròn I., A.D., Gomez M., N.O. and Robledo G., E.l. (2005) Componentes Genéticos en Pobla- 
ciones Heteróticamente Contrastantes de Maíz de Origen Tropical y Subtropical. Agronomía mesoamericana, 16, 145151.

[33] Reyes, D., Molina J.D., Oropeza M.A. and Del Carmen Moreno, E. (2004) Cruzas Dialelicasentre Líneas Autofecundadas de Maíz Derivadas de la Raza Tuxpeño. Revista Fitotecnia Mexicana, 27, 49-56.

[34] Cano-Ríos, P., Ramírez-Rosales, G., Ortegòn-Perez, J., Esparza-Martínez, J.H. and Rodríguez-Herrera, S. (2000) Análisis Dialelico para Vigor de Semilla de Melón. Agrociencia, 34, 337-342.

[35] Montenegro, T.H., Rincón, S.F., Ruiz T., N.A., León C., H. and Castañón N., G. (2002) Potencial genÉtico y Aptitud Combinatoria dé Germoplasma de Maíz Tropical. Revista fitotecnica Mexicana, 25, 135-142.

[36] Vasal, S.K., Srinivasan, G., Beck, D.L., Crossa, J., Pandey, S. and de Leon, C. (1992) Heterosis and Combining Ability of CIMMYTs Tropical Late White Maizegermplasm. Maydica, 37, 217-223.

[37] Moll, R.H., Salhuana, W.S. and Robinson, H.F. (1962) Heterosis and Genetic Diversityinvariates of Maize. Crop Science, 40, 1588-1595.

[38] Shull, G.H. (1908) The Composition of a Field of Maize. American Breeders Association, 4, 296-301.

[39] Hallauer, A.R. and Miranda, J.B. (1981) Quantitative Genetic in Mize Breeding. Iowa State University Press, Ames, Iowa. 268-368. 